\title{
Sosialisasi Penerimaan Peserta Didik Baru dengan Pendekatan Manajemen Humas
}

\author{
Mohamad Muspawi ${ }^{1}$, Gustriana Rindhi ${ }^{2}$ \\ 1,2Universitas Jambi, Indonesia \\ Correspondence email: muspawi01@gmail.com, Rindhi_18@gmail.com
}

\begin{abstract}
Abstrak. Menggambarkan tentang strategi hubungan masyarakat dalam melaksanakan kegiatan untuk menerima peserta didik baru di SMA Negeri 7 Merangin merupakan tujuan dari penelitian ini, serta mengenai faktor dan kendala ketika melakukan sosialisasi penerimaan peserta didik baru. Adapun sifat dari penelitian ini yaitu penelitian kualitatif dengan menggunakan jenis penelitian studi kasus. Objek penelitian adalah SMA Negeri 7 Merangin dengan Kepala Sekolah dan Wakil Kepala Sekolah khususnya di bidang Hubungan Masyarakat, serta perwakilan dari siswa kelas X, XI, XII sebagai subjek dari penelitian ini. Pengambilan data menggunakan teknik pengamatan, mewawancarai, serta mendokumentasikan yang kemudian dilanjutkan dengan mereduksi kembali data yang telah didapat berikut dengan penyajian serta verifikasi sehingga akhirnya dapat diambil kesimpulan. Selain itu, teknik Triangulasi juga digunakan untuk menguji keabsahan data yang telah diperoleh dari penelitian ini. Adapun hasil dari penelitian ini: (1) Program Humas SMA Negeri 7 Merangin sudah tersusun dengan baik, namun belum ada strategi jitu dalam penerimaan peserta didik baru; (2) Teknik dalam melaksanakan strategi manajemen Humas sekolah tersebut, yaitu publikasi sekolah melalui pemasangan spanduk/baliho, sosialisasi, dan melalui sosial media; (3) Pelaksanaan strategi manajemen Humas SMA Negeri 7 Merangin belum sepenuhnya tercapai, terdapat strategi yang tidak telaksana yaitu sosialisasi; (4) Faktor pengambatnya yaitu waktu serta kurangnya sumber daya manusianya serta latar belakang sekolah tersebut yang awalnya adalah sekolah swasta.
\end{abstract}

Keywords: Penerimaan peserta didik baru; Manajemen Humas.

Abstract. Describing the public relations strategy in carrying out activities to receive new students in SMA 7 Merangin is the purpose of this study, as well as about the factors and constraints when conducting socialization of the acceptance of new students. The nature of this research is qualitative research using case study research. The object of research is Merangin 7 Public High School with the Principal and Deputy Principal, especially in the field of Public Relations, as well as representatives of students of class X, XI, XII as the subjects of this study. Retrieval of data using observation techniques, interviewing, and documenting which is then followed by reducing the data that has been obtained following the presentation and verification so that conclusions can finally be drawn. In addition, the Triangulation technique is also used to test the validity of the data that has been obtained from this study. As for the results of this study: (1) the Public Relations Program of Merangin 7 Public High School has been well structured, but there is no surefire strategy in accepting new students; (2) Techniques in implementing the school public relations management strategy, namely school publications through the installation of banners / billboards, outreach, and through social media; (3) The implementation of the Public Relations 7 Merangin Public Relations management strategy has not been fully achieved, there are strategies that are not implemented, namely socialization; (4) The limiting factors are time and lack of human resources and the background of the school which was originally a private school

Keywords: Admission of new students; Public Relations Management.

\section{PENDAHULUAN}

Hubungan masyarakat atau yang sering disingkat dengan istilah humas merupakan salah satu bagian penting untuk menunjang pencapaian tujuan sebuah organisasi. Karena pada dasarnya peran dari bagian hubungan masyarakat ini adalah sebagai penghubung yang nantinya akan berguna untuk membangun suatu kerja sama dengan masyarakat. Bagian hubungan masyarakat ini juga dapat berperan sebagai informan yang nantinya bertugas memberikan segala bentuk informasi dari suatu organisasi mengenai hal-hal yang perlu untuk diketahui oleh masyarakat dari suatu organisasi tersebut. Hal ini juga senada dengan pendapat Frank Jeffkins dalam Mustari (2014:149), yang mengatakan bahwa hubungan masyarakat adalah semua kegiatan dari bentuk komunikasi dari luar maupun dari dalam terencana secara baik yang nantinya diharapkan dapat mencapai tujuan khusus, yaitu pengertian bersama. Orientasi dari peran humas sekolah adalah membangun sebuah lembaga pendidikan yang profesional, dan pembangunan sebuah lembaga penidikan menurut Muspawi (2015) tentu berorientasi pada upaya memfasilitasi peserta didik agar dapat menempuh proses pendidikan di bawah naungan pendidikan yang terlembaga dengan baik.

Hubungan masyarakat juga sangat diperlukan untuk menunjang segala bentuk kegiatan yang berhubungan dengan masyarakat luas, di setiap lembaga pendidikan khususnya dalam satuan sekolah. Hal ini juga nantinya akan berpengaruh terhadap suatu sekolah jika bagian dari hubungan masyarakat ini dapat dimanajemen dengan baik. Adapun dampak dalam memanajemen bagian hubungan masyarakat ini secara baik maka nantinya juga akan memberikan pengaruh yang positif pula bagi sebuah sekolah tersebut. Dengan pelayanan dan informasi yang telah diberikan oleh bagian Humas ini secara baik maka akan dipandang sebagai citra dan pengakuan positif di mata masyarakat terhadap sebuah sekolah tersebut. Dengan demikian, bagian hubungan masyarakat ini memiliki peran sebagai penghubung sekolah kepada masyarakat harus mampu mensosialisasikan kepada pihak luar mengenai informasi yang terkait dalam ruang lingkup sekolahnya seperti visi dan misi sekolah, informasi tentang keadaan tenaga pendidik, serta bagaimana dengan kondisi fisik sekolah seperti prasarana yang dimiliki oleh sekolah 
tersebut. Selain itu, bagian hubungan masyarakat ini juga harus mampu menjabarkan tentang program unggulan yang terdapat dalam sebuah sekolah berikut dengan prestasi-prestasi yang telah diperolah baik itu dari peserta didik maupun dari tenaga kependidikannya.

Keberhasilan sebuah penyelenggaraan lembaga pendidikan pada sebuah sekolah bergantung kepada setiap komponen pendukung seperti dalam melaksanakan kegiatan kurikulum, peserta didik, pendanaan, tenaga pelaksana, serta sarana dan prasarana. Komponen tersebut tidak dapat dipisahkan satu sama lain karena merupakan satu kesatuan untuk mencapai tujuan dari sebuah lembaga pendidikan. Dalam penyelenggaraan kegiatan belajar dan pembelajaran, salah satu komponen terpenting dari penyelenggaran pendidikan adalah peserta didik. Hal ini dikarenakan proses belajar dan pembelajaran dalam setiap lembaga pendidikan tidak akan terlaksana jika tidak ada peserta didiknya. Senada dengan hasil penelitian yang dilakukan oleh Suhardan, et. al (2014:203), mengatakan bahwa keberadaan peserta didik sangat diperlukan dalam pelaksanaan kegiatan belajar dan pembelajaran di setiap sekolah. Karena peserta didik bersifat multifungsi sebagai subjek maupun objek dalam mentransformasikan keterampilan serta ilmu pengetahuan yang diperlukan oleh setiap peserta didik. Pada setiap tahun ajaran baru tentu sekolah tidak akan lepas dari kegiatan perekrutan peserta didik baru. Kita juga sama-sama mengetahui bahwa setiap lembaga pendidikan baik negeri maupun swasta pada saat ini menerima peserta didik baru di setiap tahunnya dengan menawarkan berbagai bentuk pelayanan terbaik seputar pendidikan. Oleh karena itu, pada saat ini setiap satuan pendidikan diharapkan dapat membuat suatu terobosan terbaru mengenai cara menarik minat agar peserta didik dapat mendaftarkan diri kepada satuan pendidikan tersebut.

Bagian hubungan masyarakat sangat berperan dalam menciptakan sebuah kepercayaan dari masyarakat. Karena pada saat ini, masyarakat sudah cerdas dalam menentukan pilihannya mengenai satuan pendidikan yang akan ia pilih sebagai wadah untuk mendidik generasi selanjutnya. Dengan demikian, tentu saja masyarakat memilih satuan pendidikan yang telah memiliki kriteria dengan salah satunya yaitu pelayanan dengan kualitas terbaik sehingga nantinya diharapkan agar anaknya tersebut dapat bersaing dan melanjutkan ke perguruan tinggi yang sesuai dengan ia inginkan. Ketika satuan pendidikan mampu untuk dapat bersaing dengan satuan pendidikan lainnya maka secara tidak langsung minat banyak peserta didik akan tertarik. Sebaliknya, jika kemampuan tersebut tidak bisa dilakukan oleh satuan pendidikan tersebut maka akan berdampak kepada minat banyak peserta didik sehingga akan mendapatkan peserta didik yang bisa dikatakan kurang dari yang diharapkan atau kemungkinan terparah yang bisa menyebabkan tutupnya sekolah tersebut dikarenakan tidak ada peserta didik yang berminat.

Peran humas dalam rangka mensosialisasikan keberaaan dan program sekolah ke tengah-tengah masyarakat memang telah sejak lama telah dilakkan oleh sekolah-sekolah di dunia ini hingga kini, seperti penelitian Saifil (2017) melaporkan bahwa SMKN 1 Al Mubarkeya Ingin Jaya Aceh Besar melakukan program humas dalam rangka promosi sekolah mereka dengan dua cara yaitu dengan cara langsung dan tidak langusung, cara langsung yaitu dengan mengundang para orang tua/wali siswa dan komite sekolah untuk melaksanakan rapat, serta dengan pelaksanaan rapat tahunan sekolah. Seedangkan kegiatan tidak langsung dilakukan dengan menyampaikan informasi melalui media seperti website sekolah, E-mail, dan telepon. Termasuk dengan cara dengan cara menyebarkan brosur, promosi dari mulut ke mulut, menjalin kerjasama dengan dunia usaha serta melaksanakan serangkaian kegiatan sosial dan agama.

Dengan demikian, peran Humas di sini sangat penting serta dibutuhkan dalam kegiatan penerimaan peserta didik baru. Strategi yang harus dilakukan oleh Humas harus mampu menarik minat peserta didik baru untuk mendaftar disekolah mereka. Adapun faktor tersebut menjadi salah satu penentu sekaligus membentuk sebuah keunggulan dan juga strategi yang menentukan berhasil atau tidaknya dari sebuah proses. Seperti halnya, yang dikemukakan oleh Learned et al (dalam Akdon, 2016:13), mengatakan bahwa untuk menciptakan produk unggulan yang tak kalah saing adalah dengan mengunakakan alat berupa strategi. Oleh karena itu, Humas sekolah diharapkan harus bisa membuat produk yang berupa strategi dengan baik dan secara matang agar nantinya dapat bersaing dengan sekolah lain sehingga akan menarik minat calon peserta didik baru untuk mendaftar dan bersekolah di sekolah tersebut.

Begitu pula dengan kegiatan yang telah dilakukan oleh Sekolah Menengah Atas Negeri 7 Merangin yang telah berusaha memanajemenisasi Humasnya sehingga sekolah ini diharapkan dapat mencapai tujuan dari penyelenggaraan pendidikan. Adapun sekolah ini terletak di Dusun Bangko, Kec.Bangko, Kabupaten Merangin, Provinsi Jambi yang sekolah ini merupakan salah satu Sekolah Menengah Atas dengan terakreditasi A. Dengan Bapak Antrismen sebagai pimpinan dari sekolah ini. Dan sebagaimana mestinya sekolah ini juga melaksanakan kegiata penerimaan peserta didik baru.

\section{METODE PENELITIAN \\ Pendekatan dan Jenis Penelitian}

Penulis menggunakan pendekatan kualitatif serta mengarah pada metode jenis penelitian deskriptif. Adapun metode penelitian deskriptif ini berisikan kutipan data dengan tujuan agar dapat memberikan gambaran tentang data yang terdapat dari naskah wawancara, catatan langsung dari lapangan, foto, videotape, dokumen pribadi, memo atau catatan, serta mungkin dokumen resmi lainnya (Moleong, 2014:11).

Creswell (2010:4), mengatakan bahwa untuk mengeksplorasi dan memahami makna dari sejumlah individu ataupun sekelompok orang yang dapat dikatakan sebagai akar dari masalah kemanusiaan atau sosial adalah dengan menggunakan metode penelitian kualitatif. Sementara menurut pendapat Lincoln dan Denzim (dalam Moleong, 2014:5) yang mengatakan bahwa untuk merumuskan suatu permasalahan yang terjadi dalam sosial masyarakat adalah dengan penelitian kualitatif sebagai penelitian berlatar belakangkan alamiah sehingga nantinya dapat mengartikan suatu peristiwa yang terjadi serta dilakukan 
sebagai jalan untuk mengaitkan berbagai metode yang telah ada.

Untuk memproses data penelitian kualitatif hendaknya dilakukan dengan gambaran yang sesuai dengan kondisi secara objektif dilapangan, wajar, serta natural tanpa adanya memanipulasi data. Hal ini dikutip berdasarkan dari pendapat Arifin (2011:140). Adapun menurut pendapat Bogdan dan Taylor (dalam Arfin 2011:140) mengatakan bahwa untuk mendapatkan data secara deskriptif yang berupa kata-kata tertulis atau lisan dari yang dikatakan oleh orang-orang serta perilaku yang telah diamati adalah dengan menggunakan prosedur penelitian kualitatif.

Penelitian ini berjeniskan penelitian studi kasus sebagai metode pendekatakan untuk memperoleh pengertian secara mendalam tentang gambaran mengenai situasi serta makna dari suatu objek yang telah diteliti. Alasannya, karena tujuan penulis untuk menggambarkan hasil studi kasus secara sistematis, actual, dan akurat mengenai permasalahan yang terdapat dalam penelitian ini. Sehingga penulis dapat mengetahui gambaran dari objek penelitian dengan mudah.

\section{Subjek Penelitian}

Penelitian ini menjadikan kepala sekolah, wakil kepala bidang Humas, dan beberapa peserta didik dari SMA Negeri 7 Merangin sebagai subjek penelitian.

\section{Jenis dan Sumber Data}

Penelitian ini berjenis dan bersumber dari data penelitian yang terdiri dari data primer dan data sekunder. Data primer merupakan data yang diperoleh dari sumber pertama. Adapun data dari penelitian ini diperoleh dari hasil wawancara dengan kepala sekolah, waka bidang Humas, dan beberapa siswa SMA Negeri 7 Merangin. Sementara data sekunder merupakan data yang diperoleh dari sumber kedua seperti buku, brosur, dan artikel lainnya yang terdapat dari suatu website yang langsung berkaitan dengan penelitian ini. Ataupun data yang masih diperoleh dari orang kedua tetapi bukan jenis data yang langsung diperoleh secara langsung. Melainkan data yang dapat mendukung pembahasan dan penelitian dari beberapa sumber buku atau data yang telah diperoleh sehingga akan membantu dan mengkaji secara kritis penelitian tersebut. Oleh karena itu, untuk memperoleh data tersebut peneliti menggunakan sejumlah buku, brosur dan website serta contoh penelitian sebelumnya yang relevan sebagai data pendukung dalam penelitian ini.

\section{Teknik Pengumpulan Data}

Penelitian ini menggunakan teknik observasi, wawancara, dan dokumentasi sebagai teknik pengumpulan data.

\section{Teknik Analisis Data}

Penulis menggunakan Teknik penelahaan dalam menganalisa data penelitian ini, kemudian dilanjutkan dengan mereduksi data, dan menyajikan serta memverifikasi data sehingga dapat diambil kesimpulan dari proses menganalisis data ini.
HASIL DAN PEMBAHASAN.

Strategi Manajemen Humas Dalam Penerimaan Peserta Didik Baru di SMA Negeri 7 Merangin Program dan Strategi Manajemen Humas SMA Negeri 7 Merangin

Dengan adanya dampak dari kemajuan ilmu pengetahuan serta teknlologi seperti yang kita ketahui saat ini dapat membuat setiap lembaga pendidikan dalam meningkatkan kualitas pelayanannya sehingga diharapkan mampu bersaing ditengah ketatnya persaingan sekolah dalam berlomba-lomba untuk merekrut peserta didik baru dengan menawarkan berbagai jenis pelayanan yang berkualitas. Maka dari itu Humas sebagai salah satu bidang yang memiliki peran yang penting mencoba menyusun berbagai program ataupun strategi dalam menarik minat calon peserta didik baru.

Berdasarkan dokumen dalam Program kerja Humas SMA Negeri 7 Merangin memiliki beberapa program kegiatan yaitu kegiatan eksternal dan kegiatan internal. Adapun kegiatan Eksternal yang dimaksud tersebut berhubungan dan langsung ditujukan kepada instansi atasan serta masyarakat diluar sekolah melalui kegiatan perantara seperti misalnya informasi melalui stasiun televisi, internet khususnya pada website sekolah yang bersangkutan, radio, media cetak, pameran sekolah, majalah atau buletin sekolah, serta kegiatan yang bersifat tatap muka lainnya.

Sementara melalui kegiatan internal sekolah dapat mempublikasikan informasinya melalui rapat komite bersama, atau ketika melayani kunjungan tamu ataupun tokoh masyarakat sekitar. Dalam kegiatan internal ini bersifat penyampaian informasi ke dalam. Dengan kata lain, sasaran dari kegiatan tersebut adalah warga sekolah SMA Negeri 7 Merangin dengan melalui surat edaran sebagai media, memanfaatkan papan pengumuman sekolah, buletin sekolah, majalah dinding, pemasangan iklan dengan pemanfaatan media massa, ajang kegiatan pentas seni, rapat kerja dewan guru, ketika melaksanakan upacara bendera, serta dalam karyawisata ataupun kegiatan rekreasi bersama lainnya. Itu yang tertulis dalam program kerja tahunan Waka Humas SMA Negeri 7 Merangin dan berdasarkan pernyataan Waka Humas SMA Negeri 7 Merangin,

"Untuk program Humas sendiri kami memiliki program yang sudah dibuat yaitu terdapat kegiatan eksternal dan internal dalam Humas."

\section{Ditambahkan oleh Kepala sekolah,}

"Tentunya masing-masing bidang memiliki program, kalau untuk Humas sendiri itu ada program dengan kegiatan eksternal dan internal, eksternal ini untuk hubungan dengan pihak luar sekolah dan insternal dengan warga sekolah SMA Negeri 7 Merangin."

Berdasarkan hasil wawancara tersebut dapat disimpulkan bahwa bidang Humas SMA N 7 Merangin sudah memiliki beberapa program yang telah dibentuk dan terencana. Tentunya hal ini sangat bagus sehingga dapat memberikan gambaran yang jelas mengenai apa saja kegiatan Humas dalam sekolah tersebut. Kemudian dari kegiatan Humas SMA N 7 Merangin nantinya 
diharapkan dapat berjalan dengan baik. Karena dengan beberapa program yang terencana tersebut akan mampu mencapai tujuan yang hendak dicapai dari penyelenggaraan pendidikan.

\section{Teknik-Teknik Manajemen Humas}

Menciptakan kerjasama yang baik dengan berbagai pihak tentunya bukan hanya program saja yang dibutuhkan, melainkan perlu juga adanya teknik dalam menjalankan program-program yang sebelumnya telah direncanakan. Berbagai macam teknik yang dapat digunakan pihak Humas sekolah dalam menjalankan progam-program yang ada. Untuk Humas SMA Negeri 7 Merangin mereka belum ada strategi jitu yang direncanakan tetapi mereka melaksanakan beberapa teknik yaitu publikasi sekolah melalui pemasangan spanduk/baliho penerimaan siswa baru, sosialisasi ke $\mathrm{SMP} /$ sederajat, pemberitahuan melalui media sosial seperti What's App dan Facebook. Hal ini dikemukakan oleh Wakil Kepala Bidang Humas SMA Negeri 7 Merangin,

"Saat ini belum ada strategi jitu yang dilaksanakan tetapi kami ada memasang spanduk/baliho penerimaan siswa baru dan sosialisasi ke SMPSMP/Sederajat tertentu."

Merangin

Ditambahkan oleh Kepala Sekolah SMA Negeri 7

\begin{abstract}
"Kalau saat ini dari sisi Humas sekolah, memang saya akui belum begitu optimal, paling-paling kami memasang spanduk dijalan menuju SMA Negeri 7 Merangin ini, kemudian menyebar informasi di sosial media seperti group What's App guru serta Facebook, kemudian sosialisasi."
\end{abstract}

Dapat disimpulkan dari hasil wawancara tersebut bahwa SMA Negeri 7 Merangin memiliki beberapa teknik dalam merealisasikan program Humas sekolah yang telah direncanakan dan dirancang, namun SMA Negeri 7 Merangin mengakui bahwa saat ini memang mereka belum memiliki teknik yang jitu dalam Humas.

\section{Pelaksanaan Strategi Manajemen Humas}

Proses pelaksanaan strategi manajemen Humas oleh pihak sekolah yaitu melakukan promosi sekolah dengan pemasangan spanduk atau baliho yang berisikan bahwa sekolah tersebut menerima pendaftaran peserta didik baru pada setiap tahunnya, kemudian memasang selebaran di mading sekolah, mensosialisasikan ke SMP/sederajat, serta memberikan informasi melalui sosial media seperti What's App dan Facebook.

Pemasangan spanduk/baliho dilakukan pihak sekolah satu spanduk/baliho di jalan masuk menuju SMA Negeri 7 Merangin. Isi spanduk/baliho tersebut selain memperkenalkan SMA Negeri 7 Merangin juga terdapat informasi mengenai waktu dan syarat untuk mendaftar di sekolah tersebut. Kemudian membuat selebaran penerimaan peserta didik baru di mading sekolah sehingga warga sekolah terutama siswa SMA Negeri 7 Merangin dapat melihat dan membantu mempromosikan SMA Negeri 7 Merangin dan mengajak teman, keluarga atau tetangga untuk mendaftar di SMA Negeri 7 Merangin. Pemberitahuan selanjutnya yaitu melalui sosial media yaitu melalui Group What's App Guru dan Siswa serta Facebook. Kemudian strategi selanjutnya yaitu sosialisasi ke SMP-SMP/Sederajat, kegiatan sosialisasi ini bertujuan untuk menjalin kerja sama dengan pihak sekolah lain guna mempromosikan SMA Negeri 7 Merangin. Namun untu sosialisasi ini sendiri tidak dapat terjalankan. Hal ini disampaikan oleh Wakil Kepala bidang Humas SMA Negeri 7 Merangin,

"Pelaksanaan strategi SMA Negeri 7 Merangin ya memasang spanduk/baliho bahwa sekolah kami membuka pendaftaran penerimaan peserta didik baru pada tahun ini, dan juga ada memasang selebaran di mading sekolah kami, serta sosialisasi ke SMP-SMP/Sederajat tertentu, dalam sosialisasi kesekolah-sekolah belum terlaksana."

Berdasarkan hasil penelitian dan wawancara di atas dapat disimpulkan bahwa dalam pelaksanakaan strategi manajemen Humas yang dilakukan oleh Humas SMA Negeri 7 Merangin sudah hampir terlaksana semua mulai dari pemasangan baliho/spanduk, kemudian penyampaian melalui sosial media, namun untuk sosialisasi belum sepenuhya terlaksana dikarenakan ada penghambat dalam proses tersebut.

\section{Faktor Penghambat Pelaksanaan Strategi Manajemen Humas}

Terdapat faktor pengahambat dalam pelaksanaan strategi dalam penerimaan peserta didik ini yaitu salah satunya terbatasnya waktu yang ada dan kurangnya Sumber daya manusia. Hal ini dikemukakan oleh Wakil Kepala Bidang Humas SMA Negeri 7 Merangin mengatakan bahwa,

"Kalau dari segi penghambat, yang menjadi penghambat kami adalah waktu yang tidak tepat saat sosialisasi, serta kami kekurangan tenaga dalam sosialisasi."

Selanjutnya senada dengan pemaparan di atas, waka sarpras mengatakan penghambatnya adalah,

"Untuk saat ini yang menjadi penghambat yaitu waktu tidak mendukung disaat kami akan sosialisasi ke SMP/sederajat itu berbenturan dengan jadwal siswa yang sedang melaksanakan Try Out/pra UN serta kami juga kekurangan tenaga karena jika ada tim yang akan di utus untuk sosialisasi tentu sekolah akan ditinggal dan anak akan terbengkalai."

Kemudian pihak sekolah juga mengalami kesulitan untuk merekrut siswa karena adanya penghambat lain yaitu image atau latar belakang dari SMA Negeri 7 Merangin. Hal ini pun dikemukakan oleh Wakil Kepala Bidang Humas SMA Negeri 7 Merangin,

"Saat ini juga menurut saya yang menjadi penghambat lain yaitu latar belakang SMA Negeri 7 Merangin, karena awalnya sekolah ini adalah SMA PGRI dan masyarakat mengganggap SMA ini masih sama seperti PGRI dulu yaitu masuk sekolah pukul 
08.00 pulang pukul 09.00 WIB dan cara belajarnya masih sama tetapi pada kenyataannya sudah berubah, namun image dipandang masyarakat tidak segampag itu untuk merubahnya."

\section{Merangin,}

Ditambahkan oleh Kepala SMA Negeri 7

\begin{abstract}
"SMA Negeri 7 Merangin saat ini masih menjadi pilihan terakhir masyarakat, hal ini menurut saya dipengaruhi dari sejarah SMA ini yang dulu awalnya adalah sekolah swasta dan masyarakat mengatakan bahwa SMA ini adalah pilihan terakhir mereka."
\end{abstract}

Berdasarkan dari data hasil penelitian ini menunjukkan tampaknya SMA Negeri 7 Merangin khususnya Humas Sekolah masih terus berjuang untuk dapat melaksanakan dan menemukan cara atau strategi yang tepat sehingga mampu bersaing dengan sekolah lain dan dapat menjadi salah satu sekolah yang menjadi pilihan pertama masyarakat dan tentunya agar mampu merekrut siswa sesuai dengan target yang telah direncanakan sekolah

\section{Pembahasan}

Berdasarkan hasil temuan penelitian ini dapat menunjukkan bahwa strategi manajemen Humas SMA Negeri 7 Merangin dalam penerimaan peserta didik baru menurut kenyataan sepenuhnya program dari Humas SMA Negeri 7 Merangin sudah terencana dengan baik. Namun, dilihat dari teknik-teknik serta pelaksanaan strategi yang direncanakan belum terlaksana semua. Dan dilihat dari strategi manajemen Humas SMA Negeri 7 Merangin itu sendiri dari hasil penelitian menunjukkan bahwa SMA Negeri 7 Merangin memiliki beberapa strategi yang dilakukan yaitu promosi sekolah yang dilakukan melalui pemasangan spanduk/baliho, Memasang selebaran di mading sekolah, sosialisasi ke SMP-SMP/sederajat tertentu, kemudian penyebaran informasi melalui sosial media seperti what's app dan facebook untuk dapat mempromosikan dengan harapan calon peserta didik dapat berminat untuk mendaftar di SMA Negeri 7 Merangin tersebut. Pihak sekolah terutama Humas sudah mencoba melakukan yang terbaik. Tentunya keberhasilan sekolah untuk menarik minat calon siswa baru dalam proses penerimaan peserta didik baru dipengaruhi oleh kualitas dan kinerja tenaga pendidik dan kependidikan sekolah terutama bidang Humas sekolah itu sendiri yang saling bekerja sama membantu untuk memajukan sekolah. Dalam konteks ini serta dari hasil wawancara masi perlu adanya peningkatan terhadap kinerja bidang Humas SMA Negeri 7 Merangin serta perlu adanya perencanaan dan strategi-strategi yang lebih baik dan lebih matang lagi, karena sangat berpengaruh terhadap mutu dari sekolah.

Sebelumnya, peneliti beranggapan bahwa strategi manajemen Humas SMA Negeri 7 Merangin sudah sangat baik. Akan tetapi, hasil dari penelitian ini juga menunjukkan beberapa hal yang tidak terlaksana dengan baik seperti sosialisasi program ke sekolahsekolah tertentu. Tentunya hal ini juga berdampak tehadap minat masyarakat, karena sosialisasi ini cukup penting untuk memberikan penjelasan serta informasi mengenai apa saja seputar sekolah yang tidak diketahui masyarakat terutama calon peserta didik baru.

Temuan penelitian ini sejalan dengan penelitian Fadhillah (2017) berjudul "Strategi Promosi Penerimaan Siswa Baru di SD Muhammadiyah Alam Surya Mentari Tahun Pelajaran 2017/2018).", yang mana penelitian tersebut juga merupakan penelitian yang sifatnya kualitatif dengan jenis penelitian fenomenologi. Dalam pengumpulan datanya, penelitian tersebut menggunakan teknik observasi, wawancara, dan dokumentasi. Adapun hasil dari penelitian tersebut dapat menunjukkan bahwa dalam strategi mempromosikan kegiatan penerimaan peserta didik baru dilakukan dengan pemanfaatan internet khususnya website sekolah, buku panduan dari sekolah, kotak suara, brosur, dekorasi dilingkungan sekitar sekolah, alat tulis sekolah, seragam, sosialisasi kesekolah-sekolah, pemaparan program sekolah dengan mengundang TK dan yang terakhir yaitu dengan menggunakan spanduk sebagai media dalam mempromosikan sekolah tersebut. Terdapat beberapa kendala dalam proses mempromosikan tentang penerimaan peserta didik baru tersebut khususnya dengan menggunakan media baliho atau spanduk. Hal ini dikarenakan tidak semua spanduk dapat menjangkau keseluruhan isi kota. Namun, kendala tersebut tidak menyurutkan semangat dalam mempromosikan tentang penerimaan peserta didik baru tersebut. Hal itu terbukti dengan adanya cara lain untuk mem-back up media yang belum berjalan sesuai dengan yang diharapkan yaitu dengan mengadakan kegiatan semacam outbound kemudian di tengah tengah kegiatan tersebut beberapa brosur dan media lainnya bisa diberikan dengan seksama. Selain itu, terdapat beberapa hambatan mengenai kuota peserta didik baru yang menyebabkan sekolah yang bersangkutan kekurangan peserta didik. Hal ini dikarenakan calon peserta didik baru yang telah dinyatakan diterima di sekolah tersebut mengundurkan diri tanpa adanya pemberitahuan kepada pihak sekolah. Tetapi, untuk permasalahan tersebut sekolah dapat mengatasi dengan cara memberikan batas waktu untuk penerimaan peserta didik baru, menambah tujuan baru ketika sosialisasi ke TK.

Selain itu, hasil penelitian ini juga beriringan dengan hasil penelitian Kusuma (2016), berjudul "Strategi Pemasaran Penerimaan Peserta Didik Baru di SMK Muhammadiyyah 2 Jatinom Klaten." Penelitian tersebut berjenis penelitian kualitatif dengan menggunakan metode wawancara secara mendalam, mengobservasi, serta mendokumentasikan data yang diperoleh dari penelitian tersebut. Dari hasil penelitian itu, dapat disimpulkan bahwa: 1) Dalam strategi pemasaran penerimaan peserta didik baru di SMK Muhammadiyah 2 Jatinom Klaten berawal dengan menyelenggarakan pertemuan untuk mengoordinasikan kepada kepala sekolah beserta para guru untuk dapat menentukan rencana mengenai kegiatan penerimaan peserta didik baru. Dengan pertemuan tersebut, kepala sekolah langsung menyusun rencana agenda kegiatan berikut dengan kepanitiaan dalam rangka menyambut atau menerima peserta didik baru. Adapun dalam pertemuan tersebut langsung melibatkan Wakil Kepala dibidang kesiswaan, Wakil Kepala Sarpras, Wakil Kepala Humas, para Guru BP, Pimpinan-Pimpinan 
Program serta melibatkan beberapa Guru mata pelajaran. 2) Dalam pelaksanaan penerimaan peserta didik baru tersebut. Ditargetkan untuk kuota peserta didik baru yang bisa diterima sesuai dengan fasilitas dan daya tampung ruangan yang telah dimiliki oleh sekolah. Selain itu, kepala sekolah juga mengoordinasikan kepada masing-masing kepala yang mempunyai program pada kegiatan penerimaan peserta didik baru tersebut untuk dapat menggali tentang persepsi masyarakat terhadap program unggulan yang dimiliki oleh sekolah tersebut. 3) Strategi unggulan dalam pemasaran kegiatan penerimaan peserta didik baru yang dilakukan oleh SMK Muhammadiyah tersebut adalah dengan melakukan publikasi secara langsung seperti melakukan kunjungan ke SMP/MTs berikut dengan mempromosikan melalui soal try out UNAS kelas IX SMP. Selain itu, publikasi secara tidak langsung juga dilakukan oleh SMK muhammadiyah ini seperti memanfaatkan media elektronik maupun media cetak seperti brosur dan lain lainnya sebagai media dalam mengenalkan kepada pihak luar mengenai Sekolah yang bersangkutan ini.

Penelitian yang dilakukan oleh Martiasari (2017) dengan berjudul "Strategi Hubungan Masyarakat dalam Penerimaan Siswa Baru di Lembaga Pendidikan Islam (Studi Multikasus di MTs Ma'arif Udanawu dan SMP Muallimin Wonodadi Blitar)". Adapun hasil penelitian tersebut juga sejalan dalam penelitian ini. Karena penelitian tersebut juga sama-sama bersifat penelitian kualitatif dengan menggunakan teknik pendekatan fenomenologi. Kemudian dalam teknik pengumpulan datanya penelitian tersebut juga menggunakan teknik wawancara secara mendalam, mengobservasi partisipan serta menggunakan studi dokumentasi. Dengan demikian, penulis dapat menyimpulkan dari hasil penelitian yang dimiliki oleh Martiasari tersebut adalah sebagai berikut: (1) Dalam kegiatan penerimaan peserta didik baru lingkungan Humas telah menelaah bahwa lembaga pendidikan islam tersebut sebelum melakukan penerimaan peserta didik baru melakukan pe-mapping-an wilayah dan mengoordinasi pembagian tugas tim dalam menyampaikan informasi. Adapun tim yang dimaksud terdiri dari siswa dan guru. Selain itu, Humas juga telah melakukan penelaahan dengan menganalisa tentang keadaan masyarakat disekitar lingkungan lembaga pendidikan Islam tersebut, (2) Dalam Strategi penerimaan peserta didik baru pada publik internal lembaga pendidikan islam tersebut melaksanakan pertemuan kepala sekolah dengan guru serta berbagai kegiatan siswa lainnya, (3) Dalam strategi penerimaan peserta didik baru pada lingkungan publik eksternal lembaga pendidikan islam tersebut juga melaksanakan pembangunan jejaring kepada berbagai pihak yang dulunya pernah terlibat seperti para alumni, masyarakat pengguna, orang tua/wali dari siswa, lembaga penyelenggaraan pendidikan yang terkait yaitu Kemenag dan Kemdiknas, lembaga perantara(pengurus jama'ah tahlilan dan yasinan atau organisasi masyarakat seperti NU dan Muhammadiyah dan lain-lain), tokoh masyarakat, masyarakat umum, serta perusahaan sebagai sponsor ketika mengadakan kegiatan besar.

Penelitian Aliyannata (2016) melaporkan bahwa: 1) Strategi pelaksanaan dalam manajemen humas ketika melaksanakan kegiatan penerimaan peserta didik baru dilaksanakan dengan meliputi dua program Humas di MTs Negeri 2 Simo yaitu program kegiatan langsung dan program kegiatan tidak langsung. Adapun yang dimaksud dengan program kegiatan langsung yaitu dengan menggunakan media cetak sebagai media penunjang seperti penggunaan brosur, spanduk dan baliho. Sementara yang dimaksud dengan program kegiatan tidak langsung yaitu program kegiatan yang dilaksanakan dengan cara tatap muka secara langsung ketika bersosialisasi baik itu menggunakan bantuan media atau tanpa menggunakan bantuan media, 2) Dalam melaksanakan evaluasi program Humas sekolah tersebut dilakukan pada setiap akhir pelaksanaan program oleh penanggung jawab program yang bersangkutan kepada panitia penerimaan peserta didik baru. Dengan demikian, hasil dari penerimaan peserta didik baru pada tahun 2015/2016 tersebut dapat menunjukkan bahwa kuota untuk 74 siswa baru dapat terpenuhi pada setiap tahunnya. Hal ini juga beriringan dengan penelitian yang dilakukan di SMA Negeri 7 Merangin.

Pentingnya peran humas dalam rangka mensosialisasikan keberadaan sekolah ke tengahtengah masyarakat, dan dalam rangka sosialisasi penerimaan siswa baru juga sejalan dengan hsail penelitian A'mal (2011), Qohar (2016), Hakim (217), dan Andi (2018).

Haryanto dan Roza (2012) juga menginformasikan bahwa trend di era modern menempatkan masyarakat tidak hanya sekedar sebagai pemakai pendidikan tetapi beralih menjadi pelanggan pendidikan, di mana dengan strategi yang jitu dari bagian humas akan menjadikan masyarakat loyal untuk tidak berpaling ke sekolah lainnya. Qoimah (2018) juga menjelaskan bahwa keberadaan bagian hubungan masyarakat hendaknya berada pada tingkat manajemen puncak sehingga dapat memberikan masukan pada tingkat manajemen institusional.

\section{SIMPULAN}

Berdasarkan hasil penelitian diatas yang telah dipaparkan di bab sebelumnya, maka Berdasarkan analisis serta pembahasan hasil data penelitian yang dipaparkan dalam Bab IV, akhirnya disusun kesimpulan sebagai berikut :

1. Program Humas SMA Negeri 7 Merangi sudah tersusun dengan baik dan untuk strategi manajemen Humas di SMA Negeri 7 Merangin sendiri untuk saat ini belum ada strategi jitu yang tekonsep dengan baik dan matang.

2. Terdapat beberapa teknik yang dilakukan yaitu SMA Negeri 7 Merangin dalam melakukan strategi manajemen Humas yang ada, yaitu publikasi sekolah melalui pemasangan spanduk/baliho penerimaan siswa baru, sosialisasi ke SMP/sederajat, pemberitahuan melalui media sosial seperti whatsup, facebook.

3. Pelaksanaan Strategi Manajemen Humas di SMA Negeri 7 Merangin belum sepenuhnya tercapai. Karena terdapat strategi yang tidak dapat terlaksana sepenuhnya yaitu sosialisasi ke sekolah-sekolah.

4. Faktor penghambat dari pelaksanaan Strategi Manajemen Humas di SMA Negeri 7 Merangin yaitu waktu serta kurangnya sumber daya manusianya, 
dan yang menjadi penghambat lain yaitu image atau latar belakang SMA Negeri 7 Merangin yang awalnya adalah sekolah Swasta.

\section{Saran}

Setelah mendapatkan kesimpulan dari hasil penelitian, maka penulis dapat memberikan beberapa saran sebagai berikut:

1. Kepada sekolah selaku penanggung jawab agar lebih meningkatkan dan lebih memantau segala programprogram yang dijalankan agar telaksana dengan lebih optimal dan lebih ditingkatkan lagi kedepannya.

2. Kepada Wakil Bidang Humas sebagai salah satu bagian yang sangat penting dalam penerimaan peserta didik, agar lebih meningkatkan lagi kinerjanya dan lebih mengembangkan lagi program serta strategi hums untuk lebih meingkatkan mutu serta jumlah siswa kedepannya. Dari tahun ke tahun perlu adanya pembuatan strategi-strategi baru dengan menyesuaikan keadaan agar lebih efektif pelaksanaannya.

3. Kepada seluruh warga sekolah hendaknya lebih memperhatikan serta dapat saling membantu dalam melaksanakan kinerja Humas agar lebih optimal sehingga seluruh program serta strategi Humas yang telah direncanakan dapat dijalankan semua dan bisa lebih meningkatkan jumlah siswa kedepannya.

\section{DAFTAR PUSTAKA}

A'mal, Muslikhul. (2011). Strategi Manajemen Humas dalam Penerimaan Siswa Baru di MTs Negeri Model Pemalang. Skripsi. Program Studi Kependidikan Islam (KI). Fakultas Tarbiyah IAIN Walisongo Semarang

Akdon. (2016). Strategic management for educational management. Bandung: Alfabeta.

Aliyannata, Susana. (2016). Manajemen Strategi Humas Dalam Promosi Penerimaan Siswa Baru di Madrasah Tsanawiyah Negeri 2 Simo Tahun Pelajaran 2015/2016. Thesis. Program Pascasarjana Institut Agama Islam Negeri Surakarta Tahun 2016.

Andi, Rosalina Nurina. (2018). Manajemen Humas dalam Rangka Menarik Minat Masyarakat. Tesis. Prodi MPI Pascasarjana UIN Maulana Malik Ibrahim Malang.

Arifin, Z. (2011). Penelitian pendidikan. Bandung: Remaja Rosdakarya.

Creswell, J. W. (2010). Research design: pendekatan kualitatif, kuantitatif dan mixed. Yogyakarta: Pustaka Belajar.

Fadillah, A. (2017). Strategi promosi penerimaan siswa baru di Muhammadi yah Alam Surya Mentari tahun pelajaran 2017/2018, Skripsi, UMS, Surakarta.

Hakim, Muhaamd Abdul. (2017). Manajemen Humas dalam Peningkatan Partisipasi Orang Tua. Tesis. Prodi Pendidikan Islam FITK UIN Sunan Kalijaga Yogyakarta.

Haryanto, Rudy dan Rozza, Sylvia. (2012). Pengembangan Strategi Pemasaran dan Manajemen Hubungan Masyarakat dalam Meningkatkan Peminat Layanan Pendidikan. Jurnal Ekonomi dan Bisnis. (11). 1: 27-34
Kusuma, M. H. (2016). Strategi pemasaran penerimaan peserta didik baru di SMK Muhammadiyah 2 Jatinom Klaten, Skripsi, UMS, Surakarta.

Martiasari, N. (2017). Strategi hubungan mayarakat dalam penerimaan siswa baru di lembaga pendidikan islam (studi multikasus di MTs Ma'arif Udanawu dan SMP Muallimin Wonodadi Blitar, Skripsi, IAIN Tulungagung, Tulungagung.

Moleong, L. J. (2014). Metodologi penelitian kualitatif. Bandung: Remaja Rosdakarya.

Muspawi, Mohamad. (2015). Menganalisis Rencana Strategis Menuju Lembaga Pendidikan Berkualitas Dan Kompetitif. Jurnal IImiah Universitas Batanghari Jambi. Vol.15 No.1: 87-90. http://ji.unbari.ac.id/index.php/ilmiah/article/view/2 $03 / 199$

Mustari, M. (2014). Manajemen pendidikan. Jakarta: RajaGrafindo Persada.

Saifil, Ahmad. (2017). Peran Humas dalam Mempromosikan SMKN 1 Al Mubarkeya Ingin Jaya Aceh Besar. Skripsi. Fakultas Tarbiyah Dan Keguruan Universitas Islam Negeri Ar-Raniry Banda Aceh.

Qohar, Muhammad Abdul. (2016). Strategi Manajeme Humas dalam Meningkatkan Mutu Sekolah. Tesis. UIN Maulana Malik Ibrahim Malang.

Qoimah. (2018). Membangun Pelayanan Publik Yang Prima: Strategi Manajemen Humas Dalam Penyampaian Program Unggulan di Lembaga Pendidikan. Islamic Management, Vol: 01/ No: 02: 191-206. DOI: 10.30868/im.v1i2.269

Suhardan, D. et.al. (2014). Manajemen pendidikan. Bandung: Alfabeta. 